\title{
After the crisis and beyond the new constitutionalism? The case of the free movement of capital.
}

\author{
SACHA DIERCKX
}

\section{Ghent University}

\begin{abstract}
This article examines the "new constitutionalism" of the free movement of capital at the International Monetary Fund (IMF) after the global economic crisis. It is argued that the concept of new constitutionalism, as developed by Stephen Gill, is an indispensable concept to understand the still growing institutionalization of neoliberal policies in constitutions, laws, institutions and regulations. The free movement of capital is essential to the neoliberal project. The last attempt to further extend the constitutionalization of the free movement of capital is the IMF's newly developed approach to capital flows. This approach, while more pragmatic than earlier attempts, can be understood as part of a G7-led effort to prevent emerging markets and developing countries from installing capital controls and deviating significantly from neoliberal policies. However, emerging markets and developing countries have opposed this new IMF framework. As such, the ability of developed countries to further extend the new constitutionalism of the free movement of capital is severely weakened because of the rising powers' resistance.
\end{abstract}

Keywords: new constitutionalism, IMF, capital controls, neoliberalism, emerging markets

\section{Introduction}

It has repeatedly been posed that the global financial crisis that started in 2007 marks the end of the neoliberal era (e.g. Wallerstein, 2008; Nesvetailova \& Palan, 2010). This assumed end of neoliberalism is mainly due to two major developments. First, it is expected that the global financial crisis means that neoliberal ideas have become delegitimized (Gills, 2010). A second major evolution is the changing economic power relations between states, in particular the relative rise of emerging markets such as China, Brazil and India, countries with more state intervention in their economies than the declining West (Subacchi, 2008; Dadush \& Stencil, 2009). From a historical perspective, we could expect that these two evolutions would mark the beginning of a new global political-economic order, or "historical structure" in a neo-Gramscian conceptualization (Cox, 1983; Gill, 2008). Historically, severe economic crises often were the turning point from one historical structure to another.

The international regime on international capital mobility has been vital in this sequence of historical structures. Whereas capital controls were a fundamental element of the Bretton-Woods system, the free movement of capital is one of the main features of the neoliberal era (Helleiner, 1996;

Chwieroth, 2010). Thus, on the basis of historical experience we would expect that the crisis would once again make capital controls a common feature of the world economy. However, as Gill (1995) has stated, an additional obstacle in the transition to a postneoliberal historical structure is the "new constitutionalism of disciplinary neoliberalism". By this, he describes how neoliberalism will be harder to transcend because of its institutionalization in constitutions, laws, institutions and 
regulations. In this article, I argue that is necessary to engage with the concept of the new constitutionalism. By means of a case-study of the institutionalization of the free movement of capital at the IMF, I demonstrate that the new constitutionalism is a valuable concept to understand the institutional project that remains very well alive even after the global economic crisis.

In the first section, I elaborate on the concept of the new constitutionalism and the critiques that the concept has attracted. The second section explores how the free movement of capital has been institutionalized at different scales, and how the IMF has treated capital controls before the crisis. Next, the third section analyses how capital controls were dealt with after the crisis at the global level, specifically at the IMF. Evidence is presented that emerging markets and developing countries resist the new constitutionalism of free movement of capital. Finally, I summarize the findings and present some general lessons.

\section{The new constitutionalism of disciplinary neoliberalism}

\section{The concept of new constitutionalism}

The concept of "new constitutionalism" was introduced by Stephen Gill in the 1990s (see amongst others Gill, 1995, 1998, 2002, 2008). It was meant to reflect the growing institutionalization of neoliberal frameworks and policies into legal and quasi-legal agreements, insulating these policies from day-to-day democratic debate and decision-making. As Gill has stated, the central goal of new constitutionalism is to firmly secure the protection of private property rights, and as such to transform public policy in accordance with the interests of internationally mobile capital. This implies binding constraints on fiscal, monetary and trade and investment policies, and emphasizes values such as market efficiency, discipline, business confidence, policy credibility and consistency, and competitiveness . Via these constraints, disciplinary neoliberalism is legally encoded. Moreover, "these frameworks can be modified only in extraordinary circumstances and through burdensome procedures, often requiring special majorities or unanimity" (Lesage \& Vermeiren, 2011, p. 43).

New constitutionalism entails efforts at different scales. At the national scale, one can think of the institutionalized independence of central banks or the IMF-sponsored currency boards in the 1990s. The European Union (EU) or the North American Free Trade Agreement (NAFTA) are the main examples at the regional scale. Finally, at the global scale, the World Trade Organization is the classic case of a new constitutionalist framework that ties the hands of future governments.

There are three important aspects of the new constitutionalism that are worth stressing. First, the main purpose is to limit democratic control over economic policymaking. As such, it is a device to make sure that populations would not use democratic processes to turn back certain neoliberal "achievements". Thus, "new constitutionalism is designed to 'lock in' commitments to disciplinary neo-liberalism and to 'lock out' other potential political economy alternatives (...) partly by making many of their means (...) illegal" (Gill, 2008, p. 79).

Second, these limits to democracy are definitely not "neutral", they are strongly political in the sense that they "subordinate the universal to the particular interests of large capital" (Gill, 2008, p. 175). Thus, new constitutionalism is the political-juridical component of the neoliberal political project aimed at restoring and deepening capitalist class power (Gill, 2008, p. 163), under the predominance 
of transnational capital, in particular transnational financial capital (see also Harvey, 2005; van Apeldoorn \& Overbeek, 2012). By constraining democracy through the institutionalization of policies that favour internationally mobile capital, what is emerging is a social order in which holders of internationally mobile capital are conferred privileged rights of citizenship and representation. In effect, "the mobile investor becomes the sovereign political subject" (Gill, 1998, p. 25). As Gill (2008, pp. 138-139) states: "Central, therefore, to new constitutionalism is the imposition of discipline on public institutions, partly to prevent national interference with the property rights and entry of exit options of holders of mobile capital with regard to particular political jurisdictions." This discipline implies that the accountability of governments is increasingly to the "financial markets", instead of to national populations.

Third, while the efforts are intended to benefit transnational capital, they are part of an Americanled G-7 project (Gill, 2008, p. 142, 168). Thus, while Gill did not really explicate this aspect, it can be expected that governments in emerging markets and developing countries are less inclined to stick to the new constitutionalist frameworks than Western governments, in particular the US and EU member states.

\section{The limits to "new constitutionalism"?}

Stephen Gill's conceptualization of new constitutionalism has prompted several (sympathetic) critiques. Three interrelated arguments can be identified. First, Stephen Gill's account is too "determinist" (Strange 2002, 2006; Parker, 2008). According to Hartmann (2011, p. 565): "Law is pictured as just another political instrument at the disposal of the powerful". This determinism is mistaken, because the liberal world order designed by the West makes it possible to engage with international institutions and legal frameworks in order to change them. Thus, it is better to speak of "democratic constitutionalism" (Parker, 2008, p. 397) or "liberal global governance" (Strange, 2011, p. 544). This critique mirrors an earlier critique of the "Gramscian legacy" on international institutions (Gareau, 1996). Referring in particular to the work of Robert Cox, one of the criticisms formulated by Gareau was that the Gramscian legacy did not acknowledge that international institutions can work to delegitimize the ongoing hegemony. This resembles the critiques on Gill's concept of the new constitutionalism.

Second, because of Gill's determinism, he understates the opportunities for contestation and resistance (Strange, 2002, p. 351; Parker, 2008, p. 398). Because of the liberal modalities of global institutions and regulations, global governance can also facilitate progressive change (Strange, 2011, pp. 555-556). Constitutionalism should be seen as a "more open terrain" (Parker, 2008, p. 401), on which the rules of the global political economy can be changed (Strange, 2011, p. 544). This also explains why organizations such as labour movements or states such as China, which are resisting neoliberalism, engage with these constitutional frameworks (Parker, 2008, p. 401; Strange, 2011, pp. 543-545). Gill is, because of his determinism, too pessimist in this regard (Strange, 2002, p. 344).

These two critiques imply that, thirdly, Gill wrongly relates the new constitutionalism to neoliberalism. It is argued that this association is false: constitutionalism "might be formulated in accordance with more social-democratic political preferences" (Parker, 2008, p. 397). Gill is considered to overestimate the capacity of elites to determine these laws and constitutions 
(Hartmann, 2011, p. 565). Not all constitutional frameworks are neoliberal, and when they are, they still contain several provisions that deviate significantly from neoliberalism. According to these authors, the European Union is a case in point (Strange 2002, 2006; Parker, 2008).

The fourth and final critique is that it is not only "hard" constitutional modes of governance that are used to promote neoliberal policies (Parker, 2008). Non-legal or soft legal means may be far more important. Thus, for example, at the EU level, the importance of new constitutionalism in securing neoliberalism may be overstated. It "fails to do justice to those modes or technologies of governance other than the law via which a neoliberal hegemony could be promoted" (Parker, 2008, p. 402).

\section{Critiquing the critics}

It seems that the above critiques are mostly based on a biased interpretation of Stephen Gill's conceptualization, and a historical tendency to equate historical materialism with determinism and orthodoxy. A different reading suggests that the critiques are at least exaggerated. As to the first critique, Gill doubted the ability of new constitutionalism as a strategy to institutionalize neoliberalism in a more permanent way and to solve the crisis of social reproduction within neoliberalism (Gill, 2002, pp. 63-64, 2008 p. 176). While noting the constraints that new constitutionalist strategies have produced, he also noted the "contingent and contested character" of these constraints (Gill, 2002, p. 61). Strange (2002, p. 344, 2006, p. 227) has argued that his critique of determinism has more to do with specific case-studies than with the general theoretic approach. In any case, the concept of the new constitutionalism does not seem to imply a determinist position. Nevertheless, as noted above, it must also be recognized that when neoliberal policies are institutionalized via laws and constitutions, they are often difficult to change.

Second, Gill observed that new constitutionalism already contained efforts to contain dislocations and to co-opt political opposition to prevent a political backlash against neoliberalism (Gill, 1998, 2008). He called these efforts "trasformismo" (after Gramsci), "attempts by ruling classes and élites to co-opt and incorporate opposed political forces and their intellectual leaders in order to make their power more legitimate and sustain the prestige of their regimes" (Gill, 2002, p. 65). Moreover, he also noted that pressures and constraints that the new constitutionalism produces "vary according to the size, economic strength, form of state and civil society and prevailing national and regional institutional capabilities, and the degree of integration into global capital and money markets" (Gill, 2008, p. 142). It can be argued that this implies that large emerging markets will be less prone to new constitutionalist tendencies than small developing countries.

It is, thirdly, certainly not the case that constitutions and institutions do not contain non-neoliberal elements. It was even stated explicitly that these arrangements include "measures for dealing with the dislocations produced by fictitious commodities" (Gill, 1998, p. 26). Indeed, neoliberalism has always been a flexible project, with a "remarkable transformative capacity" (Peck \& Tickell, 2002, p. 400). Though it could be argued that in some ways there has even been less compromise with subaltern groups after the crisis (see Bruff, 2012), it is clear that in other ways the growing capacity to deal with both crises and social protest is also an inherent part of neoliberalism. As Rude (2008, p. 220) writes: "If financial instability is a means by which capital disciplines world capitalism, capital has to find a way to regulate and control it, to make a liberalized global financial system not just 
resilient enough to survive its own disorder but also resilient in such a way as to maintain its fundamental hierarchical structure." This flexibility has been highlighted by terms such as "embedded neoliberalism", "managed neoliberalism" or "social neoliberalism" (Cerny, 2008), "pragmatic neoliberalism" (Sandbrook, 2000), or even "inclusive liberalism" (Mahon, 2011). It should again be recalled that Gill doubted the effectiveness of these strategies of co-optation and incorporation, especially in the longer term.

With regard to the fourth critique, again, my reading is that Gill has never stated that "a neoliberal project [is] always to be pursued via the law" (Parker, 2008, p. 412). To the contrary, neoliberalism is a multidimensional process pursued via, amongst others, political, economic, legal, ideological and cultural instruments. However, a valuable extension to the conceptualization of new constitutionalism by Stephen Gill has been made by Adam Harmes (2006) (see also Lesage \& Vermeiren, 2011). According to him, the legal anchoring of neoliberalism should be seen in relation to neoliberalism's economic anchoring. This economic anchoring is the result of the second dimension of new constitutionalism, namely its political-geographical dimension. The free movement of capital, goods and services is (legally) anchored as one of the main drivers of neoliberal globalization. However, in the meantime, policies of market correction (social policies, taxation, labour and environmental standards) most of the time still reside at a lower scale (particularly the national scale). In this way, new constitutionalism more or less freezes a political-geographical mismatch between market promotion and market correction.

As such, internationally mobile capital is able to play off one against another political-regulatory jurisdictions at lower scales by the possibility of "regime shopping" or "regulatory arbitrage". Thus, new constitutionalism has induced national governments to embrace neoliberal-oriented policy regimes in order to thwart off potential investment strikes and/or capital flight and has enhanced the structural power of transnational capital (Gill \& Law, 1989). It has also encouraged states to install national or regional new constitutionalist frameworks as a demonstration of self-discipline to be credible in the eyes of mobile investors and corporations (Gill, 1998). Neoliberal thinkers have consciously promoted this "market-preserving federalism" to constrain government intervention by anchoring inter-jurisdictional competition (Harmes, 2006).

Thus, to sum up, the concept of "new constitutionalism" provides a useful starting point for analysing the growing patchwork of constitutions, laws and treaties institutionalizing neoliberal policies, comprising both "hard law" and "soft law". This does not imply that there is no resistance to new constitutionalism, that all these regulations comprise only neoliberal elements, or that new constitutionalism is the only instrument with which neoliberalism is strengthened and deepened.

A final observation is that the new constitutionalism should not necessarily be seen as a "conspiracy". While in certain cases and for some social forces, the purpose of new constitutionalist frameworks will certainly be to defend the interests of transnational capital, this does not imply that all new constitutionalist attempts are the result of a conscious strategy on the part of capital fractions to defend their material interests. For instance, it is plausible that for technocrats that often design these policies, ideological orientations and background may be an essential element, and they may be relatively unaware that their ideas are commensurate with the interests of transnational capital. However, it is also clear that the success of these attempts to institutionalize neoliberalism is largely dependent on the structural and direct power of transnational capital. 
That the new constitutionalism is not a conspiracy, is at the same time reassuring and discouraging. On the one hand, it implies that emerging markets are not only contesting power, which could be so large that it cannot be easily defeated. On the other hand, however, it also implies that complex and multidimensional inspirations produce the new constitutionalism, and as such, resistance must also focus on these multiple dimensions and complex motives.

\section{The constitutionalization of the free movement of capital}

\section{International capital mobility institutionalized}

The free movement of capital is of course central to the neoliberal political project. It is the foundation of the existence of transnational capital, both productive and financial capital, and it is central to the new constitutionalism of neoliberalism (Gill, 1998, p. 25, 2008, p. 113). As was explained above, it is international capital mobility which makes regulatory arbitrage possible and which produces inter-jurisdictional competition, because it provides investors and corporations with exit power. It has also induced governments to "voluntarily" establish new constitutionalist frameworks to boost "policy credibility". The free movement of capital is thus crucial to the second, political-geographical dimension of new constitutionalism. It enhances the structural power of transnational capital. As such, international capital mobility is central to the legal and economic anchoring of neoliberal policies.

As the free movement of capital is crucial to the neoliberal project, it is also itself being increasingly constitutionalized. However economically and politically difficult this would be, without this institutionalization of international capital mobility, it remains a possibility for a country to withdraw from international capital markets and to reinstate substantial control over international capital movements, which would endanger neoliberal policies in other domains as well. Therefore, the norm of free movement of capital has been legally locked-in via a patchwork of bilateral, regional and global legal and institutional mechanisms (see Schneiderman, 2000; Anderson, 2009; Chowla, 2011; Gallagher, 2011). At the bilateral level, many countries have concluded bilateral investment agreements and free trade agreements with the major industrialized countries, in the first place the US and EU-states, which strongly limits the rights of these countries to use capital controls.

Regionally, organisations such as the European Union and the ASEAN, as well as agreements such as NAFTA, have institutionalized the free movement of capital to various extents. At the global level, the World Trade Organisation has constitutionalized the freedom for certain capital movements in the General Agreement on Trade in Services (GATS), but it is at the IMF that the most important attempts to globally constitutionalize the free movement of capital have been undertaken.

\section{Capital controls and the IMF before the 2007 crisis}

When the IMF was created in 1944, capital controls were a mainstream instrument. As such, the Articles of Agreement sanctioned the use of capital controls. Article VI, section 3, stated: "Members may exercise such controls as are necessary to regulate international capital movements (...)" (IMF, 1945). Moreover, Article VI, section 1, prescribed: “A member may not make net use of the Fund's resources to meet a large or sustained outflow of capital, and the Fund may request a member to 
exercise controls to prevent such use of the resources of the Fund." To sum up, member states were given the right to use controls, and the IMF could even request governments to use them as a condition for IMF financing. This is officially still the case today.

Nevertheless, from the 1960s onwards capital controls became out of fashion (Helleiner, 1996). By the early 1990s, the IMF was a fervent proponent of capital account liberalization (see also IEO, 2005). As Chwieroth (2010, pp. 12-13) explains: "In the mid-1980s, recruitment and promotion patterns brought to senior positions a new cadre of staff members who, as a result of their professional training, were inclined to view liberalization as desirable. (...) As a result, the normative outlook of the Fund changed."

In the mid-1990s, proponents of capital account liberalization pursued the institutionalization of the new policy stance in the IMF's formal rules. In April 1997, the IMF's Interim Committee ${ }^{1}$ announced its intention to revise the IMF Articles of Agreement. At the Hong Kong meeting in September 1997, the IMF's Interim Committee adopted a statement that asked the Executive Board to complete work on the modification of the Articles. Two revisions were proposed (Abdelal, 2006). The first proposed revision would change Article I to include the promotion of the orderly liberalization of capital accounts as one of the main purposes of the Fund. A second proposal would give the Fund jurisdiction over the capital account of its members. In practice, the changes would have given the Fund much greater power over emerging markets and developing countries. They would have permitted the staff to employ conditionality to encourage capital account liberalization (Abdelal, 2006; Chwieroth, 2010).

This period in the 1990s illustrates how new constitutionalism provides a useful conceptual framework for interpreting these events. First, the changes to the Articles of Agreement would have firmly institutionalized the norm of free movement of capital, and as such one of the main principles of neoliberalism. As an amendment to the Articles requires the acceptance of three-fifths of the members, having 85 percent of the total voting power in the Board of Governors (IMF, 1945), this constitutionalization of the free movement of capital would have been very difficult to reverse. For instance, the US could use its voting power to effectively veto an amendment. Second, the proposals sought to incorporate and co-opt opponents of the new constitutionalism via the concepts of orderly liberalization and gradualism. As Jack Boorman (2003), special advisor to the Managing Director, later explained: "The intent was not to force liberalisation; it was to foster liberalisation in a way that would better ensure its benefits and minimize its potential costs". Third, the events also illustrate the contingent and contested character of new constitutionalist proposals. In the final instance, the Asian crisis threw sand in the wheels of the institutionalization of the free movement of capital, and by 1999 the proposal was taken off the agenda due to resistance from developing countries and some policymakers in advanced countries (Chwieroth, 2010; Chowla, 2011). Fourth and finally, it is also evident that neoliberalism was not only pursued via legal agreements. As explained above, without any changes to the Articles of Agreement, the staff had already changed its informal approach to capital account policies. And after the rejection of the new constitutionalist proposals, the informal approach of the staff did not change considerably. Thus, although the IMF staff started to pay greater attention to the risks of open capital accounts (IEO, 2005) and despite the increased openness to the use of temporary capital controls under certain conditions, "the staff team still clearly retains a fundamental belief in the long-run desirability of liberalization" (Chwieroth, 2010, p. 
222). It is fair to say that the Fund still acted as a "cheerleader" of capital account liberalization (IEO, 2005, p. 5) at the onset of the global economic crisis.

\section{The IMF and capital controls: towards the new constitutionalism of disciplinary pragmatic neoliberalism?}

The IMF and capital controls after the crisis

In the developed world, the crisis does not seem to have produced a backlash against open capital accounts (Helleiner, 2009). It did, however, trigger a renewed interest in capital controls in emerging markets and developing countries. Countries such as India and China have kept substantial control over international capital flows, both on capital inflows and outflows, even during the neoliberal historical structure ${ }^{2}$. The crisis led to new regulations and controls (for instance in Brazil), because emerging markets and developing countries were again hit by the volatility of capital flows, which were based more on the situation in developed countries than on fundamentals in these emerging markets and developing countries (Chowla, 2011). Partly in response to this renewed interest in capital controls, the IMF has again conducted research on capital flows and capital controls. This has culminated in several working papers, staff discussion notes and staff papers, which together have to result in a "comprehensive, flexible, and balanced approach for the management of capital flows" (IMF, 2012a).

The specifics of the framework thus far developed, especially in a framework on managing capital inflow surges in March 2011 (IMF, 2011b) and a staff paper on liberalizing capital flows and managing capital outflows (IMF, 2012a), can be summarized in five central principles (see Dierckx, 2011 for a more detailed analysis of the inflows framework). First, the staff still considers full capital mobility to be advantageous to the world economy as a whole and to individual countries in particular. While it is indicated that "recent research suggests that there is no certainty that full liberalization is an appropriate objective for all countries at all times", the last stage of the liberalization of capital flows still "eliminates all remaining controls" (IMF, 2012a). It is obvious that full capital account liberalization is still an objective of the staff (see also IMF, 2010b).

However, second, it is recognized that liberalization in general, and inflow surges in particular, can carry considerable risks, and that markets may be prone to herding behaviour. As such, "a cautious approach to liberalization is warranted" (IMF, 2012a). Sequencing and a gradual approach to liberalization are appropriate, and sound and stable macroeconomic policies and a developed financial sector are important preconditions for extensive liberalization.

Third, this does imply mean that capital controls are the "right" answer. For countries that still have comprehensive capital controls, such as China and India, the IMF argues that further liberalization would certainly be beneficial. Moreover, countries that have already liberalized, should preferably not reimpose controls. Thus "liberalization should not be seen as a "two-way street"' (IMF, 2012a). The effectiveness of controls on both inflows and outflows is questioned, and the costs of capital controls are assumed to be very high.

Fourth, capital controls should only be used in very limited circumstances. Controls on inflows may only be used when the exchange rate is not undervalued, when reserves are more than adequate or 
sterilization costs very high, when the economy is overheating so that expansionary monetary policy is not advisable, and when fiscal policy is profoundly tightened (IMF, 2011b). For dealing with outflows, "appropriate macroeconomic, structural, and financial sector policies" should primarily be used (IMF, 2012a).

Fifth, if controls on inflows are used, they should be temporary, preferably non-residency based, market-based, country-specific and designed to target the specific risk, which is mostly caused by some sort of portfolio debt or equity flows (IMF, 2011b). Thus, prudential measures are to be preferred over controls. Controls on outflows should also be temporary, and they should be "lifted as soon as certain conditions are met" (IMF, 2012a). It is stated that often market-based measures will be sufficient.

\section{Postneoliberalism or pragmatic neoliberalism?}

When assessing the meaning of the IMF's new approach, an essential observation is that the IMF always strongly emphasizes that capital controls should definitely not be used to diverge from orthodox economic policy (Ostry et al., 2010). The framework on inflows makes clear that "measures that affect inflows merit greater scrutiny because they can potentially be used to substitute for appropriate macroeconomic policies" (IMF, 2011b). In the 2012 paper, it is stated that controls "should always be part of a broader policy package that also includes macroeconomic, financial sector, and structural adjustment" (IMF, 2012a). The IEO report (2005) remarks on the staff's diverging assessment on capital controls in two countries are interesting in this respect. It considers the support for controls in one country as related to the fact that that country already had a IMFsupported program in place, whereas the country whose capital controls are rejected did not have a IMF program in place. Former Executive Director Camdessus clarifies this idea in a speech (Interim Committee, 1997): "The point is not to encourage countries to remove capital controls prematurely or prevent them from using capital controls on a temporary basis, when justified. The objective is rather to foster the smooth operation of international capital markets and encourage countries to remove controls in a way that supports the drive towards sustainable macroeconomic policies, strong monetary and financial sectors, and lasting liberalization."

Another indication that the IMF does not accept deviations from the neoliberal project is the IMF's emphasis that "policy credibility" must always be kept in mind when using controls on inflows. The framework on inflows makes this clear (IMF, 2011b): "Clear communication with the markets as to the policy objectives was seen as important in signaling the likely next steps to deal with inflows, and whether these were perceived to be part of a broader and longer term strategy to develop local financial markets and encourage financial integration. ${ }^{33}$ It is emphasized that a credible exit strategy from capital controls is crucial to preserve policy credibility (Ghosh et al., 2009) and that capital controls risk affecting investor confidence for a considerable time (IMF, 2012a). It thus still seems the case today that where capital controls are not endangering the neoliberal project, they are accepted; where they could be used to put in place less orthodox economic policies, they are rejected. This is consistent with Susanne Soederberg's (2004, p. 43) critique: "In this sense, capital controls are only to be used as a means to reach the larger end, namely, the proper (neoliberal) management of financial liberalization." 
To sum up, while there the approach certainly implies a more flexible standpoint on capital controls that deviates to a significant degree from the IMF's earlier view, the current approach remains within the neoliberal limits. The relatively limited controls that would be allowed under the framework are certainly not a threat to the power of transnational financial and productive capital. This is consistent with the observation that controls can be used to reproduce neoliberal power structures as opposed to a more equal and just society (Soederberg, 2002). As such, the IMF's approach to capital controls is better referred to as an illustration of pragmatic neoliberalism than of postneoliberalism.

\section{A renewed effort to constitutionalize the free movement of capital?}

As the current IMF framework does not deviate from neoliberalism, this article argues that it can be seen as a more subtle, and more flexible form of the new constitutionalism of neoliberalism. It contains several characteristics which were outlined in the first section of this article. First, it is an attempt to restrain the use of capital controls by emerging markets and transfer economic policy from democratic policymaking towards the IMF staff. As such, it locks in neoliberal policies, in this case the free movement of capital. This in effect subordinates national policies to the interests of transnational capital.

Second, whereas Parker (2008) associates new constitutionalism with "hard law", I would argue that this is an example of "soft law" that still firmly fits the new constitutionalist framework. Moreover, the demarcation line between the two is rather blurry. The legal status of the IMF approach is not unambiguous. It was endorsed by the IMF Executive Board in various meeting (IMF, 2011a; IMF, 2012b; see also Batista, 2012), and as such, it can be considered an official IMF policy framework. However, this does not imply that it creates legal obligations (IMF, 2011b; IMF, 2012a). On the one hand, Angel Gurria, head of the OECD stated that it's not a hard set of rules, and that it's not meant to prevent countries from using capital controls when they feel they need to (in Reddy 2011). An adviser in the IMF's Strategy Policy and Review Department said that the framework will only be used to provide policy advice (in Rastello 2011b; also IMF, 2012a). On the other hand, the framework was developed as a way to outline the "global rules of the game" (IMF 2010b, 2011b). Although it creates no legal obligations under Fund surveillance, the framework itself indicates that "it forms part of a broader effort to sharpen Fund surveillance (...)" (IMF, 2011b). Gill (2008, pp. 138-139) saw surveillance mechanisms of international organizations as an important aspect of the new constitutionalism. It is also remarkable that Nicolas Ayzaguirre, director of the IMF's Western Hemisphere Department, has declared that the IMF has the mandate to preserve the stability of the international monetary system, and that the Fund could use this mandate to suppress the proliferation of capital controls (IMF, 2011c). Paulo Nogueira Batista, Brazil's Executive Director at the $\mathrm{IMF}^{4}$, saw the framework "as an attempt to prepare the terrain for more interference by the fund in the policies of emerging-market countries" (in Talley \& Reddy, 2011).

A third aspect is that this should not be seen as a conspiracy theory. The Fund threats capital controls as a technical matter, not as a political issue. Olivier Blanchard, Director of the Research Department of the IMF, writes on his blog that "while the issue of capital controls is fraught with ideological overtones, it is fundamentally a technical one, indeed a highly technical one" (Blanchard, 2011). In this way economic policy is depoliticized, so that it can be put in the hands of technocrats and specialized economists. Consequently, it should be removed from democratic decisions. However, 
this draws attention away from the increased structural power of capital that results from capital account liberalization. Capital controls may alter the power relations between labor and capital to the advantage of the former (Crotty \& Epstein, 1996). Jayadev (2007) demonstrates empirically that open capital accounts are correlated with a lower labor share in national income. Thus, due to its neoliberal bias and technocratic values, the Fund encourages open capital accounts as apolitical "good economic policy", while it is actually engaging in a class-based project that favours internationally mobile capital.

Fourth, the project to constitutionalise the free movement of capital in the IMF is especially supported by Western governments. It is clear that advanced countries, where arguably transnational capital is strongest, are trying to develop new instruments to control the use of capital controls by emerging markets and developing countries. ${ }^{5}$ For instance, in January 2011, Nicolas Sarkozy proposed the development of "a code of conduct" by the G20, and the broadening of the IMF's role in the "surveillance" of international capital transactions (see AFP, 2011). In his speech at the opening of the G20 seminar on reform of the international monetary system in March 2011, Sarkozy stated that this code of conduct should "define the conditions under which restrictions on capital movements are legitimate, effective and appropriate to a given situation" (Sarkozy, 2011). Moreover, he also said that France was in favour of a modification of the IMF's Articles of Agreement "to broaden its supervision mandate". This has been repeated in other statements by advanced countries' officials (e.g. Bernstein, 2011; Geithner, 2011; Johnsen, 2011; Matolcsy, 2011; Swan, 2012). According to the summing-up of the Executive Board's discussion in December 2010, the future IMF view "could help establish guidelines for the purposes of the Fund's surveillance on capital account and possibly other policies affecting capital flows" (IMF, 2010a). In a 2010 paper, it was stated explicitly that the IMF should have the mandate "to identify actions that members should take or refrain from" in designing capital account policies (IMF, 2010b).

Finally, it was note above that the IMF's approach can be defined as pragmatic neoliberalism. Hence, by being to a certain extent containing elements that appear a departure from neoliberalism, the pragmatic neoliberal approach contains efforts to incorporate and co-opt resistance. The fact that the Fund endorses controls, although, as explained above, in relatively limited and extraordinary circumstances, has made some analysts talk about a turnaround in the Fund's view (Harding, 2011; Talley \& Reddy, 2011), or even "the end of an era in global finance" (Rodrik, 2009). However, these efforts to incorporate opposed political forces have not prevented the emergence of resistance.

\section{The opposition of emerging markets}

While the advanced countries statements in the International Monetary and Financial Committee (IMFC) are broadly supportive of the framework, at the same time emphasizing that capital controls should remain exceptional, some emerging markets and developing countries have been very critical. The main reason, besides the lack of focus on "push countries", has been that they consider the framework as an attempt to limit the use of capital controls. As such, they categorically contest the new constitutionalism of neoliberalism in the domain of capital controls.

The most important opponent of the framework has been Brazil. At the IMFC meeting on April 16, 2011, Brazil's finance minister Guido Mantega made a clear statement (Mantega, 2011): “We oppose 
any guidelines, frameworks or 'codes of conduct' that attempt to constrain, directly or indirectly, policy responses of countries facing surges in volatile capital inflows. Governments must have flexibility and discretion to adopt policies that they consider appropriate, including macroeconomic, prudential measures and capital controls." Clearly then, Brazil interprets the framework as an instrument to restrain the policy autonomy of member states, as only certain controls may be used, and only in certain circumstances. At the April 2012 Spring Meeting of the IMFC, Mantega reiterated his opposition to the IMF's approach, while also expressing severe criticism of the management and staff's policy advice and knowledge in the field of capital controls. He urged the Fund to rethink its approach (Mantega, 2012). Brazil's Executive Director at the IMF, Paulo Noguero Batista, has also voiced opposition to the IMF's approach on several occasions. Even before Mantega had raised concerns, shortly after the approval of the staff's framework by the Executive Board in April 2011, Batista said that Brazil opposes any attempts to restrict the policy space of the member countries (see Rastello, 2011a). Finally, Brazil has also argued "that it would be highly inappropriate and politically unsustainable to attempt to use the Fund's skewed voting power, which gives undue weight to advanced countries, to impose their agenda on developing countries that are not willing to face any restrictions on the liberty to manage the capital account" (Batista, 2012, p. 100).

However, while Brazil is clearly in the forefront in the opposition to the new constitutional approach to capital controls, it is not alone in its contestation. India has been a second pillar of the resistance to the IMF's approach (e.g. Bretton Woods Project, 2011a). At the 2012 Spring Meeting of the IMFC, India's finance minister again stated that countries must have flexibility and discretion in their capital account policies, "without a sense of stigma attached to particular instruments" (Mukherjee, 2012). The BRICS as a whole have also emphasized "the risks of large and volatile cross-border capital flows being faced by the emerging economies" (BRICS, 2012) in their summit communiqués, and according to the South African Trade minister Rob Davies, the BRICS are "wary" about the IMF's framework (in Seria, 2011).

Further resistance to the new constitutionalism has come from two constituencies composed of emerging markets and developing countries. In his April 2011 IMFC statement, Mohammed Laksaci, governor of the Banque d'Algerie, said that the IMF's framework should not be part of surveillance, and that countries should maintain policy flexibility (Laksaci, 2011). ${ }^{6}$ He repeated that the IMF's ongoing research and work on capital controls "should not compromise members" ability to adopt policies and tools which they deem appropriate to their specific circumstances" in his 2012 IMFC Spring Meeting statement (Laksaci, 2012). At the same meeting, the Minister of State for Financial Affairs of the United Arab Emirates also called for policy flexibility and said that the states in his constituency oppose "modifications of member obligations with respect to capital flows" and "constraints on countries' ability to manage volatile flows" (Al-Tayer, 2012). The criticism of the IMF's new constitutionalist approach has also been expressed in G-24 ${ }^{8}$ communiqués. In April 2011 the G24 stressed that they did not agree with the proposed IMF framework, and that countries must have flexibility and discretion to use capital controls if necessary (G-24, 2011a; also G-24, 2011b). This was reiterated in April 2012, when the G-24 also emphasized they did not agree with the approach proposed by the IMF staff and that this approach "should not result directly or indirectly in new obligations on members" (G-24, 2012). Moreover, it was underlined that capital controls should be seen as an integral part of the toolkit. Finally, resistance by emerging markets and developing countries has also received the support from non-governmental organizations such as the Bretton Woods Project (e.g. Chowla, 2011) and a range of academics (e.g. Gallagher et al., 2012). 
For now, this resistance to new constitutionalism from emerging markets and developing countries has not really resulted in significant changes, as "the policy will go ahead despite the acrimony" (Bretton Woods Project, 2011b). The framework remains unchanged. Moreover, it will not be easy to replace the framework by a more flexible approach, as this requires a majority in the Executive Board, which is still largely dominated by advanced countries. However, small accomplishments suggest that this does not have to imply a determinist or pessimist approach. For instance, while the "G20 Coherent Conclusions for the Management of Capital Flows Drawing on Country Experiences" are still strongly in favour of open capital accounts, based on neoclassical economics assumptions, they also conclude: "There is no one-size-fits-all approach or rigid definition of conditions for the use of capital flows management measures" (G20, 2011). Moreover, according to IMF analyst Eswar Prasad, resistance from emerging markets makes it difficult for the Fund to use the 2011 framework on inflows in its annual assessments of the policies of the member states (in Rastello, 2011b). Additionally, that the staff has, however restricted, legitimised the use of controls on capital outflows, despite its former resolute rejection to controls on outflows (Soederberg, 2004), indicates that it may have felt more restrained by the opposition of emerging markets.

\section{By way of a conclusion: the future of neoliberalism and the new constitutionalism}

This article has engaged with the concept of the "new constitutionalism" as developed by Stephen Gill. It has argued that this is a valuable concept to describe and understand the legal anchoring of neoliberal policies into laws and constitutions that are difficult to change or abolish. This restricts democratic decision-making in the interests of Western-led transnational capital. Contrary to common critiques, however, this does not imply a determinist position: new constitutionalism is always contingent, contested by subaltern social forces, and to some degree mixed with nonneoliberal elements to incorporate some of these subaltern forces.

The institutionalization of the free movement of capital at the IMF forms an exemplary and important case to study the new constitutionalism after the crisis. While the Fund has taken a more pragmatic stance in its approach towards capital controls, this remains broadly within neoliberal limits. As capital controls are allowed only in extraordinary circumstances for countries that are already neoliberal poster children, this does not seem to threaten the interests of transnational capital in a substantial way. However, the attempt to constitutionalize the free movement of capital is contested by emerging markets, with Brazil taking the lead. Because of the power asymmetry at the IMF, both in terms of voting power and ideational power, advanced countries have so far been more able to press forward their approach, but efforts have led to some minor victories.

What general lessons can be drawn from the study presented in this article? I would argue that there are three. First, while neoliberalism has been ideologically damaged through the global crisis, this does not yet spell the end of neoliberalism as a hegemonic project. Key features of neoliberalism such as the free movement of capital remain alive and kicking. This also means that neoliberal policies may still be increasingly institutionalized. This new constitutionalism may be practiced in a more limited or pragmatic way, but it may also live on in attempts to prevent countries to refrain from neoliberal policies. As such, for anti-neoliberal social forces it is both intellectually and politically necessary to engage with the new constitutionalism, in order to create a global institutional environment that is more open to postneoliberal policies. 
Second, how rising powers behave will be of great importance for the future of the neoliberal project. Gill $(2008$, p. 165$)$ states that the main political struggle within capitalism has been between those that want to extend and lock in the rights of capital and those that want to democratize, socialize and politically control capital. Yet, I would suggest that in this case it is a struggle between those that want to lock in the rights of transnational capital under the dominance of Western and particularly US capital, and those that reject this dominance, without necessarily envisaging more democratic control over capital, neither in the authoritarian Chinese regime, nor in the Brazilian or Indian liberal democracy. All emerging markets still seem to agree on the final goal of full international capital mobility and of gradually liberalizing capital accounts. Nonetheless, while their motives may not be inherently "progressive", the contestation of the new constitutionalism in general and of the absolute free movement of capital in particular may result in decreased structural power for transnational capital.

Finally, while emerging markets may come to play a bigger role in the global political economy, Western social forces, ideas and institutions are still crucial in the neoliberal project, as the case of the free movement of capital at the IMF demonstrates. The material, ideological and institutional power of a declining US and European Union should not be underestimated. If anti-neoliberal social forces in the Western heartland fail in their opposition to neoliberalism, we should not expect progressive social forces in emerging markets to be able to build a global postneoliberal world order. Opposition to neoliberalism in the West remains essential.

\section{Endnotes}

1. The Interim Committee is now the International Monetary and Financial Committee (IMFC), a body which is composed of central bank governors or (finance) ministers from the member states, and which reflects the composition of the Executive Board.

2. For instance, on the Chinn-Ito index, which measures policies with regard to capital controls, the US, UK and all Eurozone countries all have a rating of 2,477618, whereas Brazil's rating is 0,4343722, and China's and India's rating is -1,148165 (the higher the rating, the less capital controls). Thus, Brazil, India and China have significantly more capital controls than Western countries (Chinn \& Ito, 2011).

3. The fact that the Fund sees the development of financial markets as a worthy purpose and a prerequisite for capital account liberalization, demonstrates that the Fund still pushes countries towards financialization, which increases the power of (transnational) financial capital. This is another indication that capital controls can only be used in accordance with the neoliberal project.

4. Batista is the Executive Director for a constituency with Brazil, Colombia, the Dominican Republic, Ecuador, Guyana, Haiti, Panama, Suriname and Trinidad and Tobago.

5. This is consistent with the suggestion that whereas in a neo-Poulantzian approach states are seen as a material condensation of relationships between social forces, since international institutions "are in the final analysis the result of the condensation of different power relations 
in the individual state apparatuses, we are dealing here with a second order condensation of societal relationships of forces" (see Brand \& Görg, 2008, pp. 571-572).

6. Laksaci spoke on behalf of a constituency composed of Afghanistan, Algeria, Ghana, Iran, Morocco, Pakistan and Tunisia.

7. Al-Tayer spoke on behalf of a constituency composed of Bahrain, Egypt, Iraq, Jordan, Kuwait, Lebanon, Libya, Maldives, Oman, Qatar, Syria, United Arab Emirates and Yemen.

8. The G-24 is a group of 25 developing countries and emerging markets, namely, Algeria, Argentina, Brazil, China, Colombia, Congo, Cote d'Ivoire, Egypt, Ethiopia, Gabon, Ghana, Guatemala, India, Iran, Lebanon, Mexico, Nigeria, Pakistan, Peru, Philippines, South Africa, Sri Lanka, Syria, Trinidad \& Tobago and Venezuela.

\section{References}

Abdelal, R. (2006). Writing the rules of global finance: France, Europe, and capital liberalization. Review of International Political Economy, 13 (1), 1-27.

AFP (2011). IMF endorses some capital controls for first time. Retrieved April 5, 2011, from http://www.channelnewsasia.com/stories/afp world business/view/1120891/1/.html.

Al-Tayer, O. H. (2012). IMFC Statement by His Excellency Obaid Humaid Al-Tayer. Retrieved April 29, 2012, from http://www.imf.org/External/spring/2012/imfc/statement/eng/uae.pdf.

Anderson, S. (2009). Policy handcuffs in the financial crisis: how U.S. trade and investment policies limit government power to control capital flows. Washington D.C.: Institute for Policy Studies.

Batista, Jr., P. N. (2012). The IMF, capital account regulation, and emerging market economies. In K.P. Gallagher, S., Griffith-Jones \& J.A. Ocampo (eds.). Regulating global capital flows for long-run development (pp. 93-102). Boston: The Frederick S. Pardee Center for the Study of the Longer-Range Future.

Bernstein, N. (2011). IMFC Statement by Nils Bernstein. Retrieved April 29, 2012, from http://www.imf.org/External/AM/2011/imfc/statement/eng/dnk.pdf.

Blanchard, O. (2011). What I learnt in Rio: discussing ways to manage capital flows. Retrieved June 15, 2011, from http://blog-imfdirect.imf.org/2011/06/03/what-i-learnt-in-rio-manage-capital-flows.

Boorman, J. (2003). IMF explains capital flows proposal. Retrieved March 23, 2012, from http://www.imf.org/external/np/vc/2003/020303.htm.

Brand, U. \& Görg, C. (2008). Post-Fordist governance of nature: the internationalization of the state and the case of genetic resources - a Neo-Poulantzian perspective. Review of International Political Economy, 15 (4), 567-589.

Bretton Woods Project (2011a). Brazil, India spurn IMF capital controls framework. Retrieved September 23, 2011, from http://www.brettonwoodsproject.org/art-568564. 
Bretton Woods Project (2011b). Capital flows: IMF guidelines criticised. Retrieved April 29, 2012, from http://www.brettonwoodsproject.org/art.shtml?x=569962.

BRICS (2012). Delhi Declaration. Retrieved April 29, 2012, from

http://mea.gov.in/mystart.php?id=190019162.

Bruff, I. (2012). Authoritarian neoliberalism, the Occupy Movements, and IPE. Journal of Critical Globalisation Studies, 5, 114-116.

Cerny, P. G. (2008). Embedding neoliberalism: the evolution of a hegemonic paradigm. The Journal of International Trade and Diplomacy, 2 (1), 1-46.

Cox, R. W. (1983). Gramsci, hegemony and international relations: an essay in method. Millennium: Journal of International Studies, 12 (2), 162-175.

Chowla, P. (2011). Time for a new consensus: regulating financial flows for stability and development. London: Bretton Woods Project.

Chwieroth, J. M. (2010). Capital ideas: the IMF and the rise of financial liberalization. Princeton: Princeton University Press.

Dadush, U. \& Stencil, B. (2009). The G20 in 2050. International Economic Bulletin, November 2009. Washington D.C.: Carnegie Endowment for International Peace.

Dierckx, S. (2011). The IMF and capital controls: towards postneoliberalism? Paper presented at the $6^{\text {th }}$ ECPR General Conference, Reykjavik, August 25-27, 2011. Ghent: Ghent University.

Gallagher, K. P. (2011). Losing control: policy space to prevent and mitigate financial crises in trade and investment agreements. Development Policy Review, 29 (4), 387-413.

Gallagher, K. P., Griffith-Jones, S. \& Ocampo, J.A. (eds.) (2012). Regulating global capital flows for long-run development. Boston: The Frederick S. Pardee Center for the Study of the Longer-Range Future.

Gareau, F. H. (1996). International institutions and the Gramscian legacy: its modification, expansion, and reaffirmation. The Social Science Journal, 33 (2), 223-235.

Geithner, T. F. (2011). IMFC Statement by Timothy F. Geithner. Retrieved April 29, 2012, from http://www.imf.org/External/spring/2011/imfc/statement/eng/usa.pdf.

Gill, S. (1995). Globalization, market civilization, and disciplinary neoliberalism. Millennium: Journal of International Studies, 24 (3), 399-423.

Gill, S. (1998). New constitutionalism, democratization and global political economy. Pacifica Review, 10 (1), 23-38.

Gill, S. (2002). Constitutionalizing inequality and the clash of globalizations. International Studies Review, 4 (2), 47-65.

Gill, S. (2008). Power and resistance in the new world order. Basingstoke: Palgrave Macmillan. 
Gill, S. \& Law, D. (1989). Global hegemony and the structural power of capital. International Studies Quarterly, 33 (4), 475-499.

Gills, B. K. (2010). Going South: capitalist crisis, systemic crisis, civilisational crisis. Third World Quarterly, 31 (2), 169-184.

G20 (2011). G20 Coherent Conclusions for the Management of Capital Flows Drawing on Country Experiences. Retrieved April 29, 2012, from http://www.mofa.go.jp/policy/economy/g20 summit/2011/pdfs/annex05.pdf.

G-24 (2011a). Communiqué April 24, 2011. Retrieved April 29, 2012 from http://www.g24.org/Communiques/Com2011apr.html.

G-24 (2011b). Communiqué September 22, 2011. Retrieved April 29, 2012, from http://www.g24.org/Communiques/Com2011sept.html.

G-24 (2012). Communiqué April 19, 2012. Retrieved April 30, 2012, from http://www.g24.org/Communiques/Com2012 april.html.

Harding, R. (2011). IMF gives ground on capital controls. Retrieved April 6, 2011, from http://www.ft.com/cms/s/0/cb95f0dc-5f9e-11e0-a718-00144feab49a.html.

Harmes, A. (2006). Neoliberalism and multilevel governance. Review of International Political Economy, 13 (5), 725-749.

Hartmann, E. (2011). The difficult relation between international law and politics: the legal turn from a critical IPE perspective. New Political Economy, 16 (5), 561-584.

Harvey, D. (2005). A brief history of neoliberalism. Oxford: Oxford University Press.

Helleiner, E. (1996). States and the reemergence of global finance: from Bretton Woods to the 1990s. Ithaca: Cornell University Press.

Helleiner, E. (2009). Crisis and response. Five regulatory agendas in search of an outcome. Internationale Politik und Gesellschaft, 1/2009, 11-26.

IEO (2005). Report on the IMF's approach to capital account liberalization. Washington D.C.: Independent Evaluation Office of the International Monetary Fund.

IMF (1945). Articles of Agreement of the International Monetary Fund. Retrieved May 30, 2011, from http://www.imf.org/external/pubs/ft/aa/aa.pdf.

IMF (2010a). The Chairman's Summing-Up - The Fund's Role Regarding Cross-Border Capital Flows Executive Board Meeting 10/122 December 17, 2010. Retrieved April 29, 2012, from http://www.imf.org/external/pubs/ft/sd/index.asp?decision=EBM/10/122.

IMF (2010b). The Fund's role regarding cross-border capital flows. Washington D.C.: International Monetary Fund.

IMF (2011a). Annual Report 2011: Pursuing Equitable and Balanced Growth. Retrieved April 29, 2012, from http://www.imf.org/external/pubs/ft/ar/2011/eng/pdf/ar11 eng.pdf. 
IMF (2011b). Recent experiences in managing capital inflows - cross-cutting themes and possible policy framework. Retrieved May 24, 2011, from

http://www.imf.org/external/np/pp/eng/2011/021411a.pdf.

IMF (2011c). Transcript of a press conference by the Western Hemisphere Department of the International Monetary Fund. Retrieved June 11, 2011, from

http://www.imf.org/external/np/tr/2011/tr041511a.htm.

IMF (2012a). Liberalizing capital flows and managing outflows. Retrieved May 25, 2012, from http://www.imf.org/external/np/pp/eng/2012/031312.pdf.

IMF (2012b). Public Information Notice (PIN) no. 12/42: IMF Executive Board discusses liberalizing capital flows and managing outflows. Retrieved July 9, 2012, from http://www.imf.org/external/np/sec/pn/2012/pn1242.htm.

Johnsen, S. (2011). IMFC Statement by Sigbjoern Johnsen. Retrieved April 29, 2012, from http://www.imf.org/External/spring/2011/imfc/statement/eng/nor.pdf.

Joyce, J. P. \& Noy, I. (2008). The IMF and the liberalization of capital flows. Review of International Economics, 16 (3), 413-430.

Laksaci, M. (2011). IMFC Statement by Mohammed Laksaci. Retrieved April 29, 2012, from http://www.imf.org/External/spring/2011/imfc/statement/eng/dza.pdf.

Laksaci, M. (2012). IMFC Statement by Mohammed Laksaci. Retrieved April 29, 2012, from http://www.imf.org/External/spring/2012/imfc/statement/eng/dza.pdf.

Lesage, D. \& Vermeiren, M. (2011). Neo-liberalism at a time of crisis: the case of taxation. European Review, 19 (1), 43-56.

Mahon, R. (2011). The jobs strategy: from neo- to inclusive liberalism? Review of International Political Economy, 18 (5), 570-591.

Mantega, G. (2011). IMFC Statement by Guido Mantega. Retrieved April 29, 2012, from http://www.imf.org/External/spring/2011/imfc/statement/eng/bra.pdf.

Mantega, G. (2012). IMFC Statement by Mr. Guido Mantega. Retrieved April 29, 2012, from http://www.imf.org/External/spring/2012/imfc/statement/eng/bra.pdf.

Matolscy, G. (2011). IMFC Statement by György Matolscy. Retrieved April 29, 2012, from http://www.imf.org/External/spring/2011/imfc/statement/eng/eu.pdf.

Mukherjee, P. (2012). IMFC Statement by Pranab Mukherjee. Retrieved April 29, 2012, from http://www.imf.org/External/spring/2012/imfc/statement/eng/ind.pdf.

Nesvetailova, A. \& Palan, R. (2010). The end of liberal finance? The changing paradigm of global financial governance. Millennium: Journal of International Studies, 38 (3), 797-825. 
Ostry, J. D., Ghosh, A. R., Habermeier, K., Chamon, M., Qureshi, M. S. \& Reinhardt D. B. S. (2010). Capital inflows: the role of controls. IMF staff position note, no. 10/04. Washington D.C.:

International Monetary Fund.

Parker, O. (2008). Challenging 'new constitutionalism' in the EU: French resistance, 'social Europe' and 'soft' governance. New Political Economy, 13 (4), 397-417.

Rastello, S. (2011a). IMF's proposed guidelines on capital controls divide Board. Retrieved September 23, 2011, from http://www.businessweek.com/news/2011-04-05/imf-s-proposed-guidelines-oncapital-controls-divide-board.html.

Rastello, S. (2011b). IMF draft guidelines endorse capital controls as last resort for inflows. Retrieved October 21, 2011, from http://www.bloomberg.com/news/2011-03-31/imf-draft-guidelinesendorse-capital-controls-as-last-resort-for-inflows.html.

Reddy, S. (2011). Emerging nations reject capital plan. Retrieved May 3, 2011, from http://online.wsj.com/article/SB10001424052748703702004576268980074855142.html.

Rodrik, D. (2009). The end of an era in finance. Retrieved June 11, 2011, from http://www.projectsyndicate.org/commentary/rodrik41/English.

Rude, C. (2008). The role of financial discipline in imperial strategy. In L. Panitch \& M. Konings (eds.). American empire and the political economy of global finance (pp. 198-222). Basingstoke: Palgrave Macmillan.

Sandbrook, R. (2000). Globalization and the limits of neoliberal development doctrine. Third World Quarterly, 21 (6), 1071-1080.

Sarkozy, N. (2011). Address by the President of the French Republic Nicolas Sarkozy: Opening of the G20 Seminar on Reform of the International Monetary System. Retrieved April 29, 2012, from http://www.g20-g8.com/g8-g20/g20/english/for-the-press/speeches/opening-of-the-g20-seminaron-reform-of-the-ims.1095.html.

Schneiderman, D. (2000). Investment rules and the new constitutionalism. Law and Social Inquiry, 25 (3), 757-787.

Seria, N. (2011). BRICS 'wary' of IMF rules on capital controls, South Africa's Davies says. Retrieved February 5, 2012, from http://www.bloomberg.com/news/2011-04-17/brics-wary-of-imf-rules-oncapital-controls-south-africa-s-davies-says.html.

Soederberg, S. (2004). Unravelling Washington's judgement calls: the cases of the Malaysian and Chilean capital controls. Antipode, 36 (1), 43-65.

Strange, G. (2002). Globalisation, regionalism and labour interests in the new international political economy. New Political Economy, 7 (3), 343-365.

Strange, G. (2006). The left against Europe? A critical engagement with new constitutionalism and structural dependence theory. Government and Opposition, 41 (2), 197-229. 
Strange, G. (2011). China's post-Listian rise: beyond radical globalization theory and the political economy of neoliberal hegemony. New Political Economy, 16 (5), 539-559.

Subacchi, P. (2008). New power centres and new power brokers: are they shaping a new economic order? International Affairs, 48 (3), 485-498.

Swan, W. (2012). IMFC Statement by Mr. Wayne Swan. Retrieved April 29, 2012, from http://www.imf.org/External/spring/2012/imfc/statement/eng/aus.pdf.

Talley, I. \& Reddy, S. (2011). IMF reverses position on capital controls. Retrieved June 8, 2011, from http://online.wsj.com/article/SB10001424052748703712504576245004198979930.html.

Van Apeldoorn, B. \& Overbeek, H. (2012). Introduction: the life course of the neoliberal project and the global crisis. In H. Overbeek \& B. van Apeldoorn (eds.). Neoliberalism in crisis (pp. 1-22).

Houndmills Basingstoke: Palgrave Macmillan.

Wallerstein, I. (2008). 2008: the demise of neoliberal globalization. Retrieved June 16, 2011, from http://mrzine.monthlyreview.org/2008/wallerstein010208.html. 